\title{
The heterogeneity of wooded-agricultural landscape mosaics influences woodland bird community assemblages
}

Article

Accepted Version

Neumann, J. L., Griffiths, G. H., Foster, C. W. and Holloway, G. J. (2016) The heterogeneity of wooded-agricultural landscape mosaics influences woodland bird community assemblages. Landscape Ecology, 31 (8). pp. 1833-1848. ISSN 0921-2973 doi: https://doi.org/10.1007/s10980-016-0366-x Available at https://centaur.reading.ac.uk/61912/

It is advisable to refer to the publisher's version if you intend to cite from the work. See Guidance on citing.

To link to this article DOI: http://dx.doi.org/10.1007/s10980-016-0366-x

Publisher: Springer

All outputs in CentAUR are protected by Intellectual Property Rights law, including copyright law. Copyright and IPR is retained by the creators or other copyright holders. Terms and conditions for use of this material are defined in the End User Agreement.

www.reading.ac.uk/centaur 
Central Archive at the University of Reading

Reading's research outputs online 


\title{
The heterogeneity of wooded-agricultural landscape mosaics influences woodland bird community assemblages
}

Jessica L. Neumann ${ }^{1,2}$ (Corresponding author), Geoffrey H. Griffiths ${ }^{1}$, Christopher W. Foster $^{2}$ and Graham J. Holloway ${ }^{2}$

${ }^{1}$ Department of Geography and Environmental Science, University of Reading, Reading, UK

${ }^{2}$ Centre for Wildlife Assessment and Conservation, Department of Biological Sciences, University of Reading, Reading, UK

Corresponding author details: j.l.neumann@ reading.ac.uk

\begin{abstract}
Context

Landscape heterogeneity (the composition and configuration of different landcover types) plays a key role in shaping woodland bird assemblages in wooded-agricultural mosaics. Understanding how species respond to landscape factors could contribute to preventing 5 further decline of woodland bird populations.
\end{abstract}

Objective

To investigate how woodland birds with different species traits respond to landscape heterogeneity, and to identify whether specific landcover types are important for maintaining diverse populations in wooded-agricultural environments. 
Birds were sampled from woodlands in $582 \times 2 \mathrm{~km}$ tetrads across southern Britain. Landscape heterogeneity was quantified for each tetrad. Bird assemblage response was determined using redundancy analysis combined with variation partitioning and response trait analyses.

15 Results

For woodland bird assemblages, the independent explanatory importance of landscape composition and landscape configuration variables were closely interrelated. When considered simultaneously during variation partitioning, the community response was better represented by compositional variables. Different species responded to different landscape features and this could be explained by traits relating to woodland association, foraging strata and nest location. Ubiquitous, generalist species, many of which were hole-nesters or ground foragers, correlated positively with urban landcover while specialists of broadleaved woodland avoided landscapes containing urban areas. Species typical of coniferous woodland correlated with large conifer plantations.

25 Conclusions

At the $2 \times 2 \mathrm{~km}$ scale, there was evidence that the availability of resources provided by proximate landcover types was highly important for shaping woodland bird assemblages. Further research to disentangle the effects of composition and configuration at different spatial scales is advocated.

30 Keywords: Agriculture; bird assemblages; landscape heterogeneity; species traits; variation partitioning; woodland 


\section{Introduction}

During the $20^{\text {th }}$ Century, widespread landscape modification occurred throughout the wooded-agricultural environments of Europe, North America and Australia (Hendrickx et al. 2007; Bonthoux et al. 2012; Ikin et al. 2014). Semi-natural landscape features including woodlands, hedgerows, grasslands and heathland were removed, fragmented or transformed to allow for larger agricultural fields, stands of non-native commercial coniferous woodland and urban expansion (Firbank et al. 2007; Mason 2007). This fundamentally altered the

'landscape heterogeneity' within wooded-agricultural environments, specifically the landscape composition (number and proportion of different landcover types) and landscape configuration (spatial arrangement of different landcover types) (Heikkinen et al. 2004; Devictor and Jiguet 2007; Barbaro et al. 2007; Fahrig et al. 2011). Such changes to these two complementary components of landscape heterogeneity have been linked to rapid declines in bird species diversity across a range of habitats and have had a strong impact on the community composition of species that can be supported by a landscape (Bennett et al. 2006; Haslem and Bennett 2008; Bonthoux et al. 2012; Ikin et al. 2014; Katayama et al. 2014). As human demands on the land will continue to increase (Lawton et al. 2010), there is a need to understand the complex interactions that exist between bird communities and different landscape factors (Mortelliti et al. 2010) to manage the environment and apply conservation measures effectively.

Modern wooded-agricultural environments are a mosaic of different landcover types (Bennett et al. 2006). Within a landscape mosaic, linear features (e.g., hedgerows or tree lines) and patches of native, semi-natural and anthropogenic (e.g., urban or arable) landcover can be of high ecological value for many bird species (Daily et al. 2001; Devictor and Jiguet 2007; Haslem and Bennett 2008; Sanderson et al. 2009; Oliver et al. 2010). Evidence 
indicates that this may be due to the presence of resources such as foraging or nesting sites (Fuller et al. 2007; Kennedy et al. 2010). These could be necessary as part of an organisms life cycle (landscape complementation) or may be alternative and substitutable resources that organisms can use to supplement their resource intake (landscape supplementation) (Dunning et al. 1992; Haslem and Bennett 2008). Different landcover types are also known to provide functional connectivity (the degree to which the landscape facilitates or impedes movement among resource patches (Taylor et al. 1993)) in addition to potential nesting, foraging and breeding habitat (Osborne 1984; Hinsley et al. 1995; Hinsley and Bellamy 2000). As a result, many studies have identified the value of heterogeneous landscapes that contain a variety of different landcover types and which allow for diverse niches to coexist (Heikkinen et al. 2004; Devictor and Jiguet 2007; Sanderson et al. 2009; Bonthoux et al. 2012). Studies that have considered bird response at the community or species level have also consistently recognized that species do not respond to the composition and configuration of different landcover types uniformly (see Kennedy et al. 2010; Neuschulz et al. 2012; Katayama et al. 2014). For woodland birds specifically, Radford and Bennett (2007) found that while extent of tree cover was important for a number of species in Australia, others were more strongly affected by variables relating to landscape configuration (i.e., patch size, fragmentation and structural connectivity) or by the composition of cropped or pastoral land-use in the surrounding matrix. Haslem and Bennett (2008) also found that woodland bird populations were richer in landscapes containing greater amounts of native vegetation, while species tolerant of more open habitat associated positively with scattered trees. Nonetheless, we still have a relatively limited understanding of the ecological value of different landcover types for woodland birds in intensively-modified temperate landscapes that are typical of much of

80 Europe (see Hinsley et al. 1995; Bellamy et al. 1996; Hinsley and Bellamy 2000). If modern wooded-agricultural environments are to be effectively managed in a way that is beneficial to 
woodland bird communities, a thorough understanding of exactly how species respond to, and interact with the multiple landcover elements that comprise a landscape mosaic is required (Bennett et al. 2006; Barbaro et al. 2007; Devictor and Jiguet 2007; Haslem and Bennett 2008). Ultimately this demands an approach that can accurately quantify the different components of landscape heterogeneity, ascertain their relative explanatory importance and capture the varying responses of different species that make up the woodland bird community.

This study explores how woodland bird assemblages respond to the composition and configuration of landscape mosaics in the intensively farmed region of southern Britain (Figure 1). The use of redundancy analysis (RDA) combined with variation partitioning and response trait analyses allows for an in-depth look at how different species respond to individual landscape elements and identification of species-landscape interactions at a community level (Heikkinen et al. 2004; Schweiger et al. 2005; ter Braak and Šmilauer 2012). It is widely accepted that species life-history traits that have been forged in response to environmental conditions over time determine how individuals respond to landscape heterogeneity and ultimately shape community composition (Schweiger et al. 2005; Tscharntke et al. 2005; Mayfield et al. 2010). However, research that simultaneously investigates the importance of specific landscape features for woodland bird communities and the explanatory role of species individual life-history traits and ecological groupings remains limited (see Hausner et al. 2003; Barbaro and van Halder 2009; Kennedy et al. 2010; Neuschulz et al. 2012; Ikin et al. 2014). Although previous studies have yielded some divergent findings (likely to be a result of surveys conducted across a range of biogeographic regions and at different spatial scales), there is the consistent indication that species which exhibit similar responses to landscape variables in a particular region tend to share combinations of the same traits. Adopting a trait-based approach in intensively modified 
wooded-agricultural environments may, therefore, help to identify groups of woodland birds that are more sensitive to landscape modification and provide a better indication of how community assemblages may continue to shift as a result of ongoing landscape change

110 (Oliver et al. 2010; Dray et al. 2014).

Four questions are addressed: i) how do woodland bird assemblages respond to the composition (the number and proportion of different landcover types) and configuration (the spatial arrangement of different landcover types) of wooded-agricultural landscape mosaics? ii) Do individual landscape features or combinations of features have a significant explanatory effect on woodland bird assemblages? iii) What is the relative importance of landscape composition and landscape configuration for shaping woodland bird assemblages, and can greater understanding be achieved by considering both these components of landscape heterogeneity together? Finally, iv) can the response of woodland bird assemblages to landscape heterogeneity be determined by five bird life-history and ecological traits? It is expected that woodland bird assemblages will respond to both measures of landscape heterogeneity (composition and configuration) at a $2 \times 2 \mathrm{~km}$ scale. It is also anticipated that different bird species will respond to different landcover types and that this will relate to species individual life-history traits.

\section{Methods}

\section{Study region}

The study was carried out across the wooded-agricultural environment of central-southern England (Figure 1). The region is low lying with an average elevation of 116 metres above sea level, and the principal soils are clay-enriched brown earths and calcareous lithomorphic substrate. The climate is temperate, with a mean annual temperature of $10.2^{\circ} \mathrm{C}$ and precipitation averaging $85.0 \mathrm{~cm}$. 


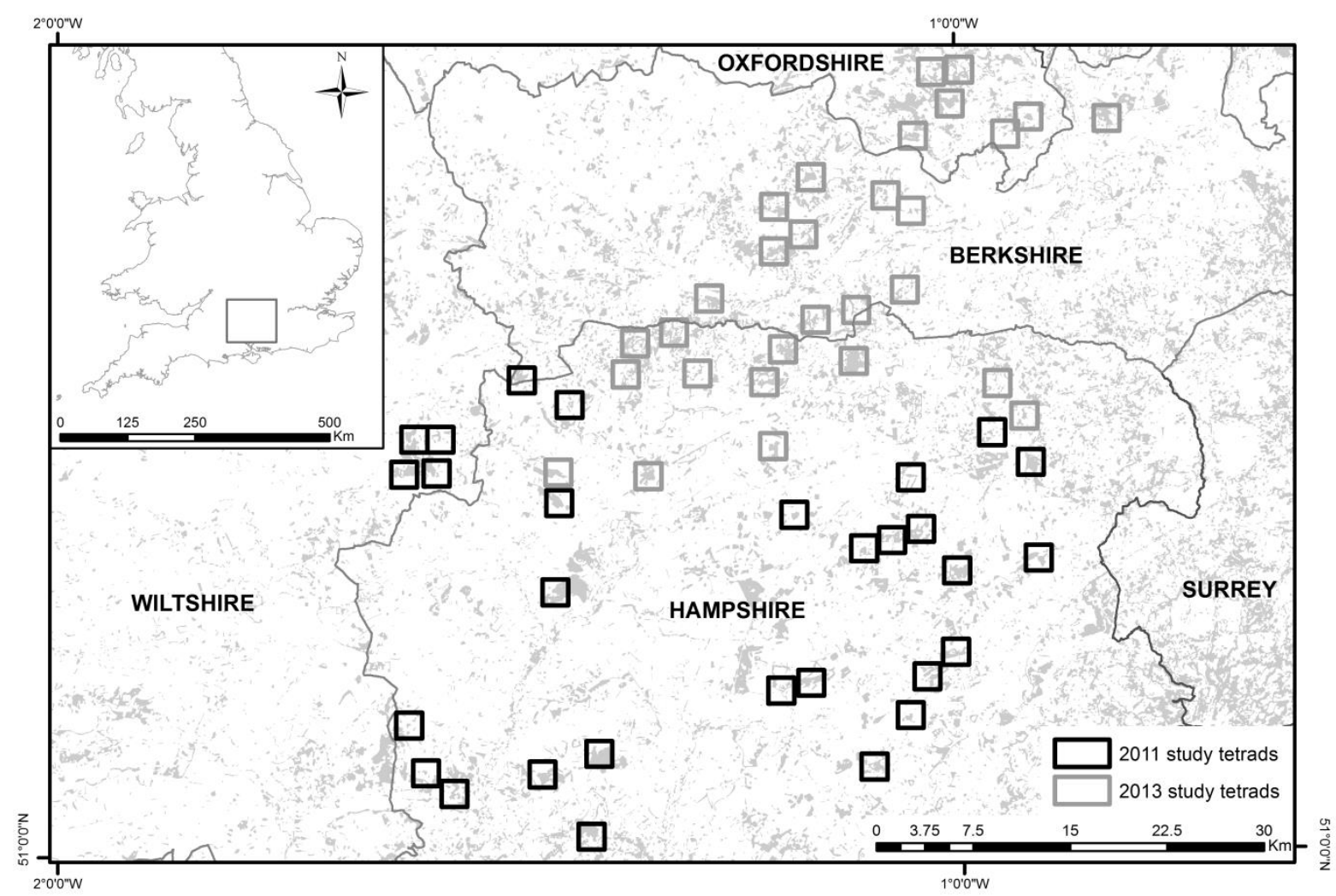

Figure 1: Location of the study region and $582 \times 2 \mathrm{~km}$ study tetrads in central southern England. Grey shading indicates broadleaved and mixed woodland cover derived from CEH Landcover 2007 (Morton et al. 2011).

\section{Study design}

Woodland bird assemblages were recorded from the centre of 58 woodland sites, hereafter called the survey woodlands. At their centre, all survey woodlands were classified as broadleaved, although some larger woods also contained stands of mixed tree composition and coniferous plantation (Forestry Commission 2011). Survey woodlands were chosen to represent a varied range of patch sizes, shapes and configurations within the landscape. A 2 x $2 \mathrm{~km}$ study tetrad was placed around each survey woodland providing 58 study landscape mosaics across the study region (Figure 1). Previous studies have identified significant bird responses at similar spatial scales, e.g., 500 x 500m (Heikkinen et al. 2004), 1 x 1 km (Haslem and Bennett 2008; Sanderson et al, 2008). This size was also deemed large enough to incorporate variation in landscape heterogeneity, while being small enough to allow 
replication without tetrad overlap across the study region (Radford and Bennett 2007). To ensure study landscapes were characteristic of lowland wooded-agricultural environments, tetrads avoided large urban areas, floodplains and coastal regions (Radford and Bennett 2007). It was also ensured that variations in slope, elevation and aspect (derived from a Digital Terrain Model (Ordnance Survey 2012)) were statistically comparable between all study tetrads. The dominant landcover types within the study tetrads were arable land, improved grassland and broadleaved and mixed woodland. Other landcover types included coniferous woodlands, semi-natural grasslands, areas of scrubland and scattered trees, inland water bodies, small urban areas and hedgerows.

\section{Woodland bird surveys}

Woodland birds were surveyed at the centre of each of the 58 survey woodlands by one ornithologist (CWF) using the static point count method (Bibby et al. 1992; Haslem and Bennett 2008; Bonthoux et al. 2012; Mattsson et al. 2013). Twenty-nine woodlands were surveyed between 11th April and 28th May 2011. The remaining 29 woodlands were surveyed between 15th April and 1st June 2013. All surveys were conducted between 0500 and 1000 hours and avoided rainy, hot or windy conditions (Haslem and Bennett 2008).

Survey woodlands were visited twice following a randomised order, enabling residents whose vocal activity tails off earlier in the spring and late arriving migrants to be detected (Heikkinen et al. 2004; Barbaro and van Halder 2009). Each point count was five minutes in duration and had no fixed radius; all birds seen or heard during this period were recorded (Bibby et al. 2000). Five minute point counts are commonly used by studies which seek to quantify bird communities over large areas (Dawson and Bull 1975; Jiguet et al. 2011). Using a short interval reduces the chance of erroneously recording the same individual twice, and it was assessed that little extra site diversity would be captured by using a longer time window (Sorace et al. 2000; Sutherland 2006; Jiguet et al. 2011). Bird records from both survey visits 
were pooled to provide a representation of the total community assemblage for each survey woodland.

\section{Life history traits and ecological groupings}

Bird species were grouped according to five life-history traits and ecological groupings (refer to Appendix 1 in Supplementary Material) to ascertain the influence of different ecological traits on bird community response to landscape heterogeneity (Hausner et al. 2003; Barbaro and van Halder 2009; Kennedy et al. 2010). Species body mass (g) was obtained from average published estimates; where mean values were different for males and females an average was taken (Snow and Perrins 1998; BTO 2014). Three categories were used to record the dominant food sources consumed during the breeding season (invertebrates, invertebrates and seeds, invertebrates and fruits) and species were also grouped according to their preferred foraging strata (ground or herb layer $(<0.5 \mathrm{~m}$ ), shrub layer (up to $3 \mathrm{~m}$ ), foliage gleaner, feeding on branches, feeding on trunks and diverse foragers) (BTO 2014). Nest locations encompassed 5 categories (ground or herb layer $(<0.5 \mathrm{~m}$ ), shrubs (up to $3 \mathrm{~m}$ ), trees or woody hedges, holes (in trees, nest boxes or buildings) and variable) (Barbaro and van Halder 2009; Ferguson-Lees et al. 2011). Finally, habitat associations (broadleaved woodland, coniferous woodland, mixed woodland, open woodland, woodland edge, shrub habitat and ubiquitous) were based on the most frequent habitat occurrence for each species according to results from the BTO Breeding Birds Survey (BTO 2014).

\section{Landscape heterogeneity spatial analysis}

190 ArcMap 10.1 (ESRI 2011) was used to digitize and quantify the landscape heterogeneity in each 2 × $2 \mathrm{~km}$ tetrad. Three groups of explanatory variables were recorded: (i) 9 landscape composition variables (number and proportional cover of different landcover types), (ii) 8 
landscape configuration variables (metrics representing shape and spatial patterning of the different landcover types) and (iii) 2 additional constraining variables (Table 1).

Table 1: Summary of the landscape composition and landscape configuration variables calculated for each $2 \times 2$ $\mathrm{km}$ study tetrad. Table includes mean, minimum and maximum values from the 58 study tetrads.

\begin{tabular}{|c|c|c|c|}
\hline Landscape variables & Mean & Min & Max \\
\hline \multicolumn{4}{|l|}{ Landscape composition model } \\
\hline Broadleaved and mixed woodland ${ }^{a b}$ & 115.4 ha & 30.8 ha & 226.2 ha \\
\hline Coniferous woodland ${ }^{a b}$ & 11.9 ha & 0 ha & 78.3 ha \\
\hline Scattered trees and scrub ${ }^{a}$ & 4.4 ha & 0 ha & 26.8 ha \\
\hline Arable land ${ }^{\mathrm{c}}$ & $124.0 \mathrm{ha}$ & 5.9 ha & 274.3 ha \\
\hline Improved grassland $^{\mathrm{c}}$ & 77.1 ha & 7.9 ha & 166.2 ha \\
\hline Urban areas ${ }^{a}$ & 33.4 ha & 0.5 ha & $161.8 \mathrm{ha}$ \\
\hline Semi-natural grassland ${ }^{\text {a }}$ & 14.9 ha & 0 ha & 86.1 ha \\
\hline Managed hedge ${ }^{d}$ & $6.3 \mathrm{~km}$ & $1.1 \mathrm{~km}$ & $15.4 \mathrm{~km}$ \\
\hline Woody hedge $^{\mathrm{d}}$ & $11.1 \mathrm{~km}$ & $1.0 \mathrm{~km}$ & $33.3 \mathrm{~km}$ \\
\hline \multicolumn{4}{|l|}{ Landscape configuration model } \\
\hline Number of woodland patches & 16 & 3 & 28 \\
\hline Mean woodland patch area & 11.2 ha & 2.0 ha & 79.7 ha \\
\hline Total length of woodland edge & $22.9 \mathrm{~km}$ & $7.2 \mathrm{~km}$ & $36.8 \mathrm{~km}$ \\
\hline Area of survey woodland patch & 180.1 ha & 1.0 ha & 530.4 ha \\
\hline Length of survey woodland edge & $16.9 \mathrm{~km}$ & $0.5 \mathrm{~km}$ & $46.1 \mathrm{~km}$ \\
\hline Distance to nearest urban area & $0.7 \mathrm{~km}$ & $<0.1 \mathrm{~km}$ & $2.0 \mathrm{~km}$ \\
\hline Survey wood - hedge connections & 9 & 0 & 72 \\
\hline Total length of transport routes ${ }^{e}$ & $1.7 \mathrm{~km}$ & $0 \mathrm{~km}$ & $7.0 \mathrm{~km}$ \\
\hline \multicolumn{4}{|l|}{ Additional constraining variables } \\
\hline Survey year & \multicolumn{3}{|c|}{ Year of survey (2011 or 2013) } \\
\hline Spatial location & \multicolumn{3}{|c|}{ Tetrad midpoint (XY coordinate) } \\
\hline
\end{tabular}

Data obtained from: ${ }^{\text {a) }}$ Ordnance Survey MasterMap data (OSMM) (Ordnance Survey 2010); ${ }^{\text {b) }}$ The National 
and ${ }^{\text {d) }}$ field survey with reference to Google Maps aerial imagery (Terra Metrics 2009) in some cases; ${ }^{\text {e) }}$ OS Open Source: Strategi (Ordnance Survey 2012).

\section{Defining landscape composition}

A measure of landscape composition included the dominant landcover types within the matrix, plus other landcover types which might be expected to be of ecological importance for woodland birds (Table 1). Some landcover variables comprised more than one habitat type to ensure that the heterogeneity of the landscape mosaic was represented using the most parsimonious number of variables. Stands of broadleaved and mixed woodland are often contiguous within a woodland patch, thus areas classified as broadleaved woodland

210 (Ordnance Survey 2010) or mixed woodland containing $50-80 \%$ broadleaved species (as recorded by the Forestry Commission 2011) were combined to form the 'Broadleaved and mixed woodland' variable (Table 1). Mixed woodland recorded as containing $50-80 \%$ coniferous species (Forestry Commission 2011) was grouped with coniferous plantation (Ordnance Survey 2010) to form the 'Coniferous woodland' variable. Scattered trees and scrub encompassed all forms of open canopy tree cover, such as orchards, parkland trees and scrubland (Ordnance Survey 2010). Urban areas were defined by residential buildings, gardens, industrial areas and manmade surfaces (Ordnance Survey 2010). Semi-natural grasslands were predominantly rough low-productivity grasslands but also contained small areas of calcareous and neutral grasslands (Ordnance Survey 2010; Morton et al. 2011). Hedgerows were surveyed during fieldwork and were divided into two categories: i) lowlying (c. $1.8 \mathrm{~m}$ height) intensively managed or flailed hedgerows typical of field boundaries ('managed hedge') and ii) hedgerows containing woody species, shrubs or mature trees greater than $c .1 .8 \mathrm{~m}$ height which were less intensively managed ('woody hedge'). All hedgerows were digitised as vector line features and followed the field parcel boundaries 
provided by the OS MasterMap data (Ordnance Survey 2010). Where required (i.e., due to land access limitations), the location of hedgerows were validated by reference with Google Maps aerial imagery (Terra Metrics 2009). The clip and union functions in ArcMap 10.1 (ESRI 2011) were used to create a seamless landcover dataset with no overlap between the different variable layers for each study tetrad.

\section{Defining landscape configuration}

A range of metrics were chosen to represent the landscape configuration within each study tetrad. These related to the shape, size and spatial pattern of broadleaved and mixed woodland patches. The spatial arrangement of landcover variables that were of significant importance in the landscape composition model were also considered, as was the total length of main transport routes (motorways, primary roads and railways (Ordnance Survey 2012)) that could act as a deterrent or pose a barrier to movement for some species (Creegan and Osborne 2005; Polak et al. 2013) (Table 1). Patches of broadleaved and mixed woodland were defined as separate where the edge-to-edge Euclidean distance between patches exceeded 30 metres; this is a guideline value considered to be an acceptable gap-crossing distance between patches for birds occupying a woodland habitat network (Forestry Commission 2001; Creegan and Osborne 2005). The Euclidean distance to the nearest urban area and number of managed hedgerows connected to the edge of the survey woodland were included to indicate whether bird assemblages were more affected by the spatial location, or spatial extent of these variables within a study tetrad. All metrics were calculated within each $2 \times 2 \mathrm{~km}$ tetrad, with the exception of where survey woodlands extended beyond the tetrad boundary. In these cases, the total patch area and length of edge habitat for the survey woodland was measured to ascertain whether any relationship between focal patch area and woodland bird assemblages exists (e.g. Lindenmayer et al. 2002; Radford and Bennett 2007). 


\section{Additional constraining variables}

250 Constraining variables can hamper the detection of true landscape effects on woodland bird communities (Table 1). During analyses, the effects of surveying across different years and spatial autocorrelation were considered (Heikkinen et al. 2004; Oliver et al. 2010).

\section{Statistical analyses}

The effects of landscape composition and landscape configuration on woodland bird communities were explored using partial redundancy analyses (pRDA), specialised response trait analyses and variation partitioning methods conducted using the Canoco v.5 software (ter Braak and Šmilauer 2012). The following parameters were applied for all analyses: partial methods were used to account for, and remove any variation that could be attributed to surveying in different years. The date, time and weather conditions of each survey were not

260 found to have a significant effect on the woodland bird community and so were not included as covariates in any of the analyses. A selection of the landscape composition variables (those measured in ha (Table 1)) were $\log (\mathrm{x}+1)$ transformed to maximise the linearity of their relation and to ensure that the ecological importance of all the landcover types was considered (Cleveland 1993; ter Braak and Šmilauer 2012; Neumann et al. 2015). Analyses were restricted to 'woodland-dependent' species (Radford and Bennett 2007) according to information from the UK Breeding Bird Surveys (BTO 2014). Species for which the survey method was not appropriate and colonial nesters were also excluded; these included wood pigeons, corvids and raptors. Of the 50 species identified during the surveys, analyses were performed on 32 species. could best explain the community composition of woodland birds. The effects of landscape composition and landscape configuration were run as two separate models. In both cases, a 
constrained ordination containing all the explanatory variables (Table 1) was run to check for significance of the joint effects; a global permutation test was considered significant where $\mathrm{p}$ $<0.05$ using 9999 Monte-Carlo permutations. Analyses were terminated at this stage if the results of the global permutation test were not significant due to the potential for Type 1 error. The correlation matrix and variance inflation factors (VIF) were consulted during the global permutation tests to check for collinearity (ter Braak and Šmilauer 2012). Correlation coefficients among the final explanatory variables were all less than 0.6 ( $c f$. Aviron et al. 2005; Radford and Bennett 2007; Neumann et al. 2015) and VIF were less than 6.5. Following a significant result, partial interactive forward selection (pIFS) was used to identify a subset of variables from each model that best summarized the bird community variation; significance was determined by $\mathrm{p}<0.05$. Results were displayed as correlation biplots, which illustrated the most important bird species relationships with key landscape variables. On the bi-plots, arrows representing bird species and landscape variables point in the direction of the steepest increase in a variables value. The relationship between a species and a landscape variable can be obtained by perpendicularly projecting the species arrowhead onto the landscape arrow. The further a species projection point falls in the direction of a landscape arrowhead, the higher the positive correlation; those that lie in the opposing direction indicate negative correlation, while a projection that falls at the origin represents near-zero correlation. The approximated optimum for each bird species in respect to a landscape variable's value was obtained using this perpendicular projection and a calibration tool available within the Canoco software. This inference of niche optima is underpinned by some assumptions (see Legendre and Legendre 1998 p.600), but provides a useful indication of species responses in respect to different landscape values (ter Braak and Šmilauer 2012).

Specialised response trait analyses were used to analyse the part of the variation in bird community assemblages that could be explained by individual species life-history traits 
and ecological groupings (Appendix 1). Similar to RLQ analyses (see Barbaro and van Halder 2009; Dray et al. 2014) this multivariate species-based approach uses a third data table containing trait information for each species (Šmilauer and Leps 2014). In Canoco, trait analyses are conducted in two sequential stages. First, the response of the bird community to landscape variables is quantified (using the variables identified during pIFS). The second step uses the response variable scores from step 1 (i.e., scores that characterised species response to the landscape variables) as the response variables, and the traits possessed by the species community as the explanatory variables. The final result is a model that predicts (using Monte-Carlo permutations) species response to the landscape variables using known traits possessed by the whole community. Importantly, different trait and ecological groupings often interrelate; as a result species responses can frequently be attributed to combinations of traits and care should be taken not to rely solely on singular traits to explain the community distribution (Barbaro and van Halder 2009). To account for potential trait correlations, the second step of analyses considered all the traits simultaneously and an interactive forward selection procedure was applied to select the traits that best explained the community response. A global permutation test on all the trait variables was run prior to forward selection to check the overall model significance $(\mathrm{p}<0.05)$.

Two forms of variation partitioning were conducted. The first tested for the effect of spatial autocorrelation using principal coordinates of neighbour matrices (PCNM) (see Borcard and Legendre 2002). Tetrads in close proximity to each other can possess more similar landscape or biotic conditions and therefore, statistically similar species communities, than those from a random set of observations (Heikkinen et al. 2004). The PCNM method separates the variation explained by spatial location from that explained by landscape predictor variables (composition or configuration) by representing space as geographic (X Y) Euclidean distances among cases (Borcard and Legendre 2002). The second form of variation 
partitioning analysed the unique (independent) contributions of the landscape composition and landscape configuration variables (identified by pIFS), plus their shared effect in explaining woodland bird community variation. By assigning each group of variables to a covariate role in turn, this test identified whether woodland bird communities could be better explained by only landscape composition variables, only landscape configuration variables, or whether both components together had an additive explanatory effect.

\section{Results}

\section{Woodland bird community dynamics}

A total of 1419 individuals from 50 bird species were recorded within all the survey woodlands. Analyses were performed on 1311 individuals representing 32 woodland species. Blue tit (C. caeruleus) was the most commonly recorded species (157 individuals equating to $12 \%$ of the total). Other frequently encountered species included wren (Troglodytes troglodytes) $(139 ; 11 \%)$, blackbird (Turdus merula) $(108 ; 8 \%)$, great tit (P. major) $(107 ; 8 \%)$, robin (Erithacus rubecula) $(104 ; 8 \%)$, blackcap (Sylvia atricapilla) $(89 ; 7 \%)$, coal tit (Periparus ater) $(83 ; 6 \%)$ and chaffinch (Fringilla coelebs) $(81 ; 6 \%)$.

\section{Landscape composition and woodland bird communities}

Partial redundancy analysis (pRDA) to test the joint effects of all landscape composition variables explained $22.6 \%$ of the total variation in woodland bird communities $(\mathrm{F}=1.5, \mathrm{p}<$ 0.001). Partial interactive forward selection identified four explanatory variables explaining $14.2 \%$ (Table 2, Figure 2). The amount of urban cover within a tetrad explained the greatest variation $(4.4 \%, \mathrm{p}=0.003)$. Other key variables included the amount of coniferous woodland, length of managed hedge and amount of broadleaved and mixed woodland (Table 2). 
Table 2: Response of woodland bird communities to variables measuring the composition and configuration of the landscape mosaic within 58 study tetrads. Results show the key explanatory variables for each model and present the life-history traits and ecological groupings which best explain bird community response.

\begin{tabular}{|c|c|c|c|c|c|c|c|c|c|}
\hline \multirow{2}{*}{$\begin{array}{l}\text { Landscape } \\
\text { model }\end{array}$} & \multicolumn{3}{|c|}{ Global permutation test } & \multicolumn{3}{|l|}{ Interactive forward selection } & \multicolumn{3}{|l|}{ Response trait analyses } \\
\hline & Var & $\mathbf{F}$ & p value & Key variable & Var & p value & Key traits / ecological group & Var & $p$ value \\
\hline \multirow[t]{5}{*}{ Composition } & $22.6 \%$ & 1.5 & $<0.001$ & Urban areas (ha) & $4.4 \%$ & 0.003 & Wood association: Coniferous & $11.3 \%$ & $<0.001$ \\
\hline & & & & Coniferous woodland (ha) & $3.8 \%$ & 0.013 & Wood association: Broadleaved & $9.7 \%$ & 0.008 \\
\hline & & & & Managed hedgerow (km) & $3.2 \%$ & 0.025 & Nest location: Hole & $8.4 \%$ & 0.013 \\
\hline & & & & Broadleaved \& mixed woodland (ha) & $2.8 \%$ & 0.065 & Foraging: Ground/ herb layer & $6.5 \%$ & 0.039 \\
\hline & & & & & & & Foraging: Branches & $6.0 \%$ & 0.049 \\
\hline \multirow[t]{4}{*}{ Configuration } & $19.2 \%$ & 1.4 & 0.008 & Survey wood edge (m) & $4.6 \%$ & 0.003 & Wood association: Coniferous & $25.3 \%$ & $<0.001$ \\
\hline & & & & Transport routes $(\mathrm{m})$ & $2.7 \%$ & 0.090 & Nest location: Hole & $8.7 \%$ & 0.021 \\
\hline & & & & & & & Wood association: Ubiquitous & $7.3 \%$ & 0.037 \\
\hline & & & & & & & Wood association: Edge & $7.1 \%$ & 0.034 \\
\hline
\end{tabular}

'Var' = percentage of variation in bird community composition explained. 


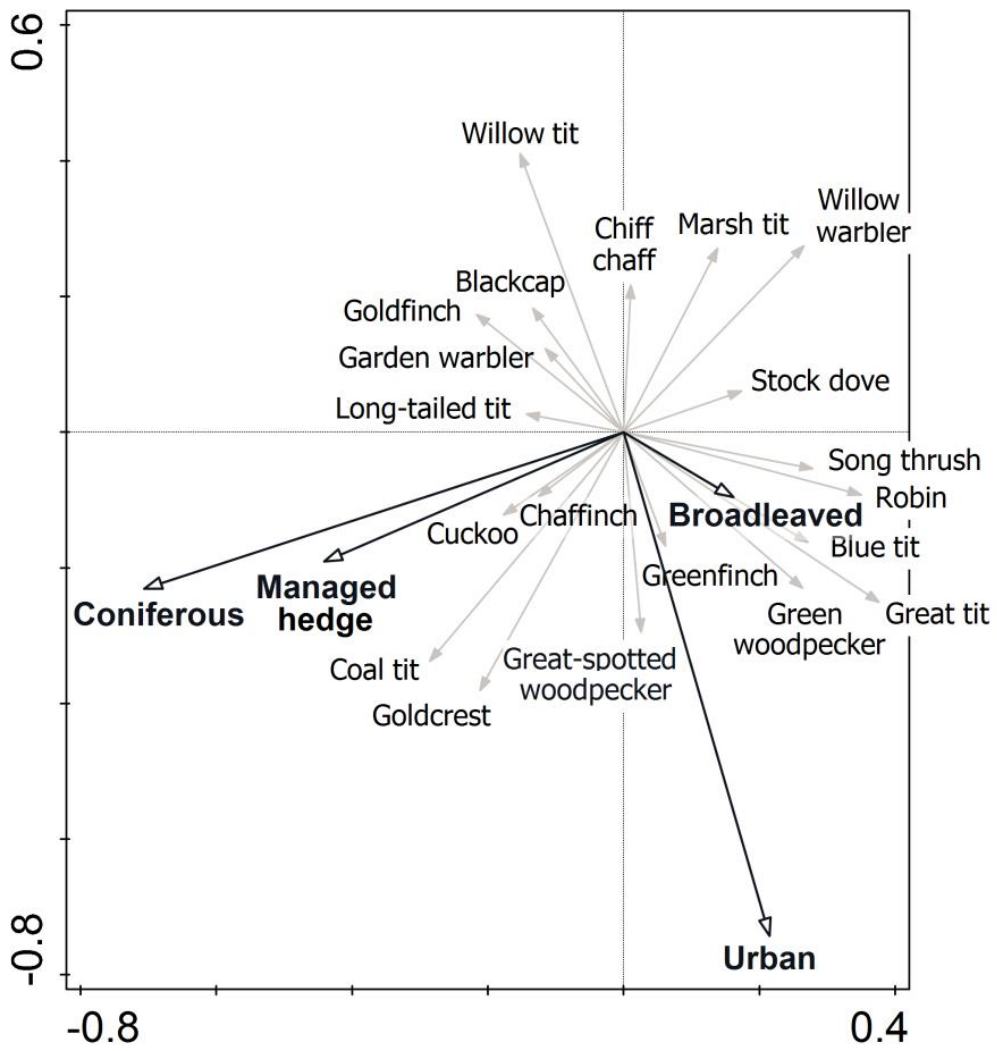

Figure 2: Partial redundancy analysis (pRDA) correlation bi-plot illustrating key landscape composition variables explaining differences in woodland bird assemblages as identified by partial interactive forward selection (pIFS). Bi-plot displays 20 species with the largest fit in the ordination space.

'Coniferous' = coniferous woodland; 'Broadleaved' = broadleaved and mixed woodland.

Species most positively correlated with urban landcover included great tit, goldcrest (Regulus regulus), great spotted woodpecker (Dendrocopus major), green woodpecker (Picus viridus), coal tit, blue tit and greenfinch (Chloris chloris). Willow tit (P. montanus) correlated negatively with urban areas and were optimally associated with landscapes containing less than 3\% urban landcover (Figure 2). Coal tit and goldcrest responded most positively to greater amounts of coniferous woodland and managed hedgerow within tetrads. Their approximated optimal requirements favoured $1.5 \%$ coniferous woodland cover (mean $2.9 \%$ ), $7 \mathrm{~km}$ of managed hedgerow (mean $6.3 \mathrm{~km}$ ) and 6\% urban landcover (mean 8.4\%). Other species that correlated positively with managed hedgerows were cuckoo (Cuculus canorus) and chaffinch. Bird species most negatively correlated with coniferous woodlands included 
willow warbler (Phylloscopus trochilus), robin, great tit, song thrush, marsh tit (Poecile palustris), blue tit and stock dove (Columba oenas). Many of these species responded positively to increased amounts of broadleaved and mixed woodland cover.

Species trait combinations relating to woodland association, nest location and foraging strata accounted for $41.9 \%$ of the variation in woodland bird communities explained by the four landscape composition variables (Table 2). Species typical of coniferous woodland ( $\mathrm{p}<0.001)$ such as coal tit and goldcrest, and species that forage on branches $(\mathrm{p}=$ 0.049) correlated with coniferous woodland cover and managed hedgerow. Species that prefer broadleaved woodlands without mixed or coniferous elements (e.g., willow tit and marsh tit $)(p=0.008)$ correlated with landscapes that contained low amounts of urban landcover. Species that frequently nest in holes $(\mathrm{p}=0.013)$ and species that forage on the ground or in the herb layer $(\mathrm{p}=0.039)$ associated with landscapes containing greater amounts of urban landcover and broadleaved and mixed woodland.

\section{Landscape configuration and woodland bird communities}

The joint effects of all the landscape configuration variables when tested together was significant and explained $19.2 \%$ of the variation in woodland bird community composition (F $=1.4, \mathrm{p}=0.008)$. Two key explanatory variables were identified (Table 2 , Figure 3 ). The length of the survey woodland edge explained $4.6 \%(\mathrm{p}=0.003)$, and the total length of transport routes also indicated a small effect (2.7\%) on bird community composition although this variable was not significant $(\mathrm{p}=0.090)$ (Table 2$)$. 


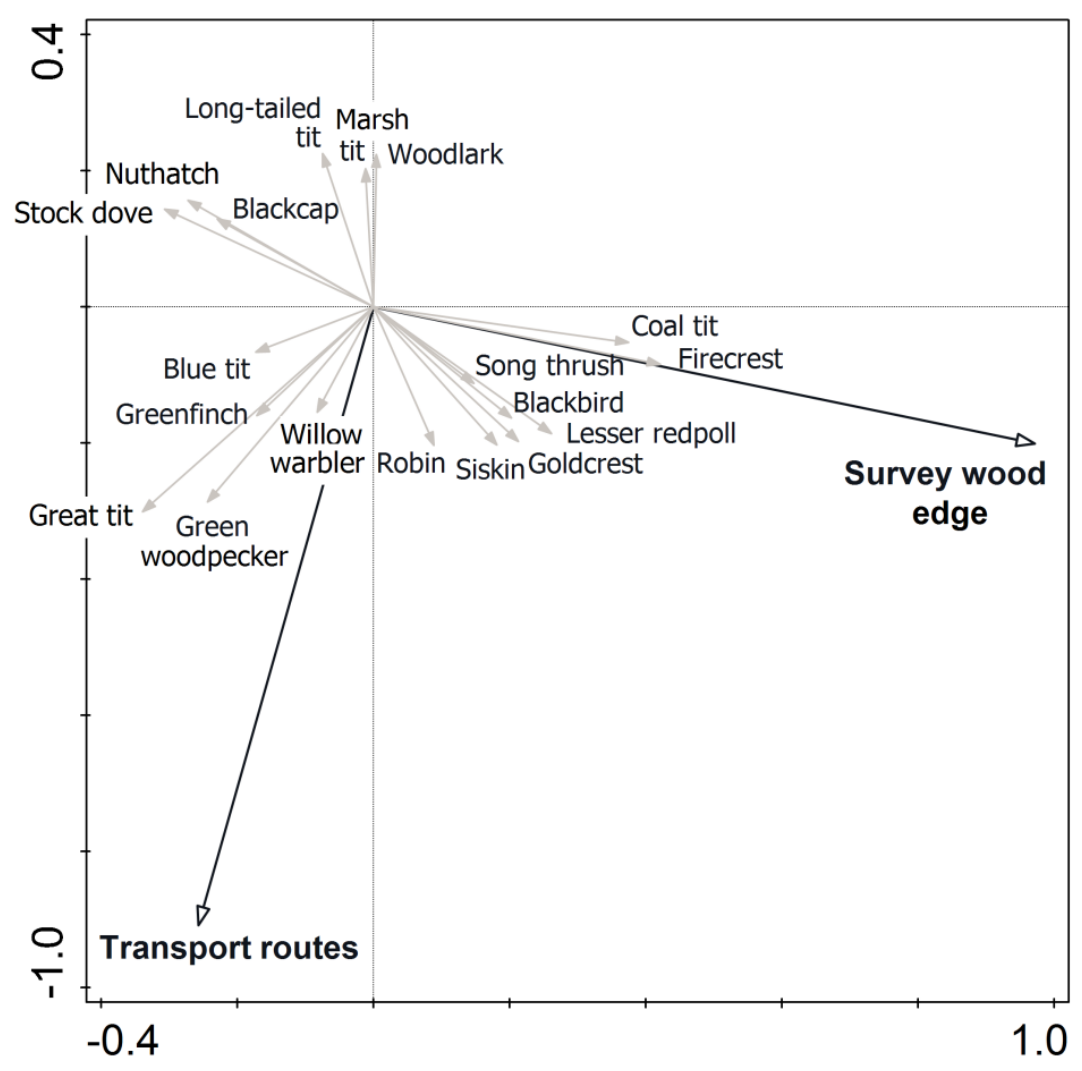

Figure 3: Partial redundancy analysis (pRDA) correlation bi-plot illustrating key landscape configuration variables explaining differences in woodland bird assemblages as identified by partial interactive forward selection (pIFS). Bi-plot displays 20 species with the largest fit in the ordination space.

Birds that correlated most strongly with increased amounts of survey woodland edge habitat were firecrest (Regulus ignicapilla), coal tit, lesser redpoll (Acanthis cabaret), goldcrest and siskin (Carduelis spinus) (Figure 3). Their approximated optimal requirement was for greater than $21 \mathrm{~km}$ of edge habitat (mean length across the study tetrads was $16.9 \mathrm{~km}$ (Table 1)). Of the species shown, great tit and green woodpecker correlated most positively with increased lengths of transport routes within study tetrads (Figure 3). Marsh tit, longtailed tit (Aegithalos caudatus) and woodlark (Lullula arborea) correlated negatively with transport routes (Figure 3).

Woodland association and nest location were significant trait groupings that accounted for $48.4 \%$ of the variation in woodland bird communities explained by the length 
of survey woodland edge and transport routes (Table 2). Species typical of coniferous woodland $(\mathrm{p}<0.001)$ correlated positively with increased lengths of survey woodland edge, while hole nesters $(\mathrm{p}=0.021)$ and ubiquitous species $(\mathrm{p}=0.037)$, notably blue tit and great tit correlated with lower lengths of survey woodland edge. Species typically associated with woodland edges $(\mathrm{p}=0.034)$ correlated with increased lengths of survey woodland edge habitat and decreased lengths of transport routes.

\section{Variation partitioning}

PCNM:

(a) Landscape composition vs. space

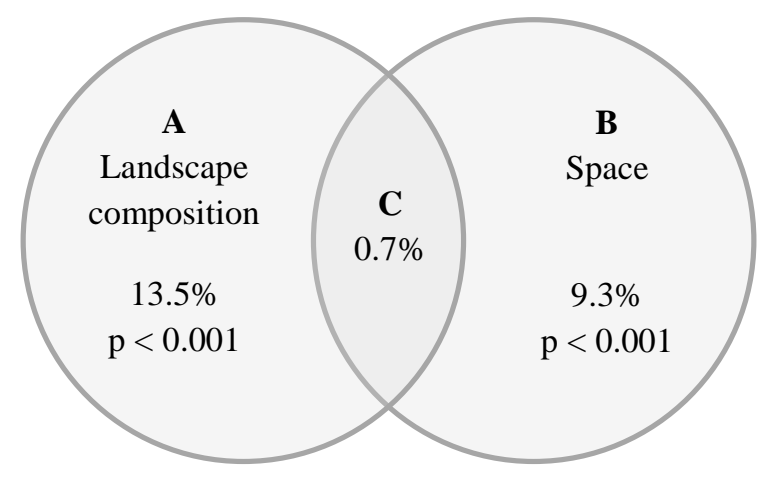

(b) Landscape configuration vs. space

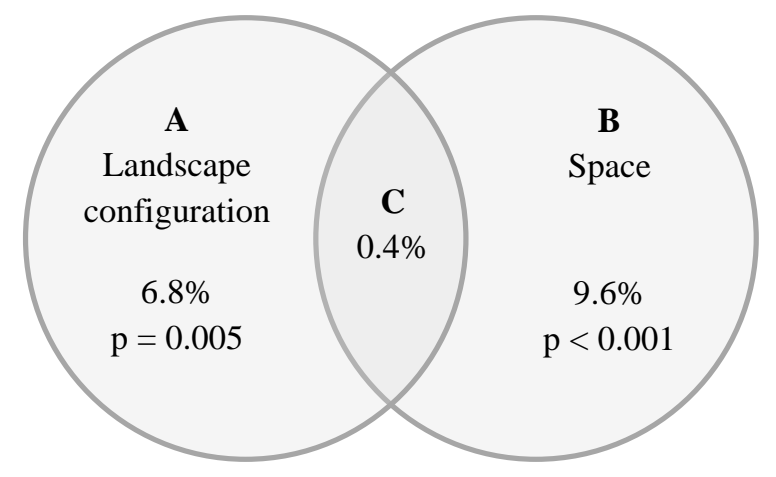

Variation Partitioning:

(c) Landscape composition vs. landscape configuration

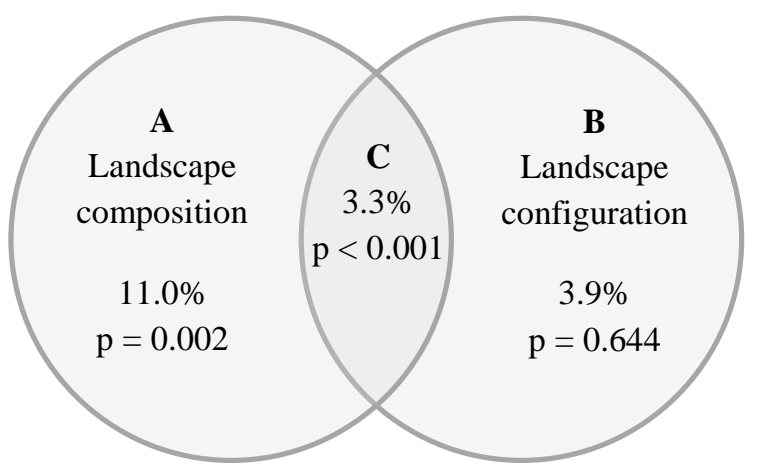

Figure 4: Results of PCNM and variation partitioning explaining woodland bird community composition.

PCNM: Fractions of variation explained by (a) landscape composition variables and (b) landscape configuration variables versus space. A and B represent the variation explained by landscape predictors and space 
respectively, $\mathrm{C}$ indicates the shared effect.

Variation Partitioning: Fractions of variation explained by (c) landscape composition variables and landscape configuration variables. A and B represent the unique effects of landscape composition and landscape configuration variables respectively, $\mathrm{C}$ indicates their shared effect.

\section{Effect of spatial location}

Principal coordinates of neighbouring matrices (PCNM) identified a degree of spatial autocorrelation in woodland bird assemblages: $10 \%$ of the variation in bird community composition could be explained by the spatial location of survey woodlands relative to one another $(\mathrm{p}<0.001)$. However, by partialling out the effects of spatial location, PCNM identified virtually no spatially conditioned variation in the landscape composition or landscape configuration variables $(0.7 \%$ and $0.4 \%$ shared effect respectively) that could explain the community assemblage of woodland birds (Figure $4 \mathrm{a}$ and $4 \mathrm{~b}$ ).

\section{Unique and shared effects of landscape composition and configuration}

Variation partitioning identified the unique explanatory contribution of the four landscape composition variables, the two landscape configuration variables and the proportion of explanatory power shared by both models. The total amount of variation explained by both composition and configuration variables (after removing any effect explained by survey year) was $18.2 \%(p<0.001)$ (Figure $4 c)$. The largest proportion of this variation was attributable to landscape composition variables, which after removing the effects of the two landscape configuration variables explained $11.0 \%(p=0.002)$. Once account had been taken of landscape composition, the amount of unique variation explained by landscape configuration was lower and non-significant $(3.9 \%, \mathrm{p}=0.664)$. The shared effect was $3.3 \%(\mathrm{p}<0.001)$ and represents explanatory overlap between both models. The non-significant unique effect of the landscape configuration variables indicates that a large proportion of the variation explained by survey woodland edge and transport routes could also be explained by the landscape 
composition variables. Comparing Figures 2 and 3, many species that correlated with increased survey woodland edge habitat and transport routes were those that responded to increased amounts of coniferous and urban landcover respectively.

\section{Discussion}

\section{The role of landscape heterogeneity in shaping woodland bird assemblages}

Woodland bird populations are continuing to decline and there is an increasing need to understand how species are influenced by the composition and configuration of modern wooded-agricultural landscape mosaics (Haslem and Bennett 2008; Mortelitti et al. 2010; Ikin et al. 2014). The use of 2 x $2 \mathrm{~km}$ study tetrads successfully captured the variation in landscape heterogeneity while allowing for the control of other confounding factors, such as topography.

In both models, different groups of birds correlated significantly with different combinations of landscape elements and species response could be determined, in part, by individual species life-history and ecological traits. Contrasting responses by different groups of species is consistent with other studies that have adopted a community-level approach (e.g., Bennett et al. 2006; Haslem and Bennett 2008; Bonthoux et al. 2012; Mattsson et al. 2013) and supports the idea that, as relatively mobile organisms, woodland birds respond to the availability of different complementary or supplementary resources provided in the surrounding matrix (Dunning et al. 1992; Fuller et al. 1997; Rodewald 2003; Virkkala et al. 2004; Devictor and Jiguet 2007; Fahrig et al. 2011). At this spatial scale, the community assemblages of woodland birds were also better explained by landscape composition variables than those representing the configuration of the landscape mosaic; a result which is broadly consistent with other studies (e.g., Atauri and de Lucio 2001; Virkkala et al. 2004;

Heikkinen et al. 2004; Barbaro et al. 2007; Radford and Bennett 2007). Heikkinen et al. 
(2004) have suggested that at finer spatial scales (c. $500 \times 500 \mathrm{~m}$ to $2 \times 2 \mathrm{~km}$ ) birds relate strongly to the extent of proximate landcover types, while at larger scales the effects of surrounding landscape composition may be less important (Atauri and de Lucio 2001). The independent explanatory effect of broadleaved and mixed woodland was also found to be small; suggesting that although the extent of focal habitat is important for woodland bird assemblages, conditions provided in the wider matrix can have an overriding or synergistic influence (Pino et al. 2000; Haila 2002; Kupfer et al. 2006).

Although the landscape composition variables provided overriding explanatory significance during variation partitioning, we believe that there remains a valid need to consider the independent importance of landscape configuration. As is discussed below, there is clear evidence that for bird assemblages at the $2 \times 2 \mathrm{~km}$ scale, landscape composition and configuration closely interrelate (see also Heikkinen et al. 2004). To fully understand this interrelation and to confirm the presence of a shared effect at other spatial scales and with different species pools, studies should continue to consider both components simultaneously (Bennett et al. 2006; Barbaro et al. 2007).

\section{The shared effect of landscape composition and configuration}

Four landscape composition and two landscape configuration variables were identified as being important for shaping woodland bird assemblages. In the composition model, urban areas appeared to be beneficial for species known to utilise garden feeding stations, such as great tit, blue tit, coal tit and great spotted woodpecker (Bennett et al. 2006). By contrast, specialists of broadleaved woodland, such as marsh and willow tit which avoid open habitats (Broughton et al. 2010, Siffczyk et al. 2003) were rarely found in landscapes that contained more than $3 \%$ urban landcover, well below the mean amount of $8.4 \%$ measured across all the tetrads (Table 1). A number of the species that were associated with urban landcover were 
also affiliated with transport routes in the configuration model, and vice versa (Figures 2 and 3). More transport routes are inherently linked with greater amounts of urban landcover (although not statistically correlated in this study), which could contribute to the explanatory overlap between the two models during variation partitioning. Transport routes are known to modify the composition of woodland bird communities due to a deterioration in habitat quality, excessive noise, decreased breeding success and increased mortality risk (Reijnen and Foppen 2006; Fahrig and Rytwinski 2009; Polak et al. 2013). However, at the 2 x 2 km scale, the explanatory importance of transport routes was only loosely inferred, possibly because the impacts tend to be relatively localised (Fahrig and Rytwinski 2009).

The extent of coniferous landcover was the second most important variable in the composition model, with species such as goldcrest and coal tit that typically inhabit coniferous woodland responding most strongly. The same group of species were linked to increased amounts of survey woodland edge in the configuration model. Survey woodlands with greater lengths of edge habitat are indicative of woodland patches that are large and/ or irregularly shaped (McGarigal and Ene 2012). Throughout the study region, the majority of conifer plantations are sited within large patches of broadleaved woodland (Rackham 2003; Forestry Commission 2011; Natural England 2013). This association by coniferous species to edge habitat may therefore, be a proxy for the fact that survey woodlands containing conifer blocks tend to be larger and have more available woodland edge than patches solely comprising native tree species.

The overriding importance of landscape composition and a high degree of explanatory overlap is consistent with other avian-based studies that have sought to disentangle the effects of composition and configuration at similar spatial scales (e.g., Heikkinen et al. 2004; Barbaro et al. 2007; Mimet et al. 2014). The relative contribution of both components is known to vary between study systems depending on the scale at which landscape 
heterogeneity is measured, the taxonomic group in question and species life-history traits; notably those relating to movement and dispersal ability and habitat specialism (Schweiger et al. 2005; Barbaro et al. 2007; Barbaro and van Halder 2009; Neumann et al. 2015). Woodland birds are relatively mobile organisms in comparison with other many other taxonomic groups (Barbaro and van Halder 2009). As a result, the influence of landscape configuration and how this facilitates bird species movement and dispersal in the long term, may override that explained by landscape composition and immediate resource availability if considered at broader spatial scales.

\section{The role of life-history traits and ecological groupings}

Species possess combinations of traits that make them more (or less) sensitive to variations in landscape heterogeneity within a particular environment (Schweiger et al. 2005; Barbaro and van Halder 2009). In this study, the response of different groups of species to specific combinations of landscape features could principally be explained by traits relating to woodland association, in combination with nest location and foraging strata. Previous studies have indicated that bird species can relate strongly to the extent of preferred or avoided habitats in a landscape (see Haila et al. 1996). While in some cases this has been attributed to the spatial clustering of habitat types (e.g., Heikkinen et al. 2004; Barbaro et al. 2007), preferences by different groups of species have also been observed in studies where bird assemblages were spatially independent of landcover distribution (e.g., Virkkala et al. 2004; Radford and Bennett 2007; Haslem and Bennett 2008). The association between species typical of coniferous habitats and the extent of coniferous woodland (and by proxy, survey woodland edge habitat) in the landscape was, therefore, not unexpected. A similar correlation existed between birds that inhabit woodland edges and increased lengths of woodland edge habitat. However, broadleaved woodland specialists including marsh tit and willow tit did not positively correlate with increased amounts of broadleaved and mixed woodland, but were 
negatively associated with greater amounts of urban and coniferous landcover. This suggests that for some specialists, the extent of unfavourable or avoided landcover types may be of greater importance than the extent of preferred habitat, as was first documented by Haila et al. (1996).

The significance of traits relating to nest location and foraging strata further highlights that resource availability and conditions provided in the surrounding matrix are important at the $2 \times 2 \mathrm{~km}$ scale. Specifically, ubiquitous species, hole-nesting birds and those foraging in the ground or herb layer correlated positively with urban areas. This was most likely due to the dominance of these groups by common species such as blue tit and great tit (hole nesters), blackbird, wren and robin (ground layer foragers) which may be capitalising on resources left unexploited by the absence of woodland specialists, effectively homogenising the woodland bird community.

\section{Conclusions}

A relatively modest amount of variation was explained by landscape composition and configuration in this study (22.6\% and $19.3 \%$ respectively), indicating that other unmeasured factors are responsible for the unexplained variation. This finding is not unique and a number of authors have indicated that high quality local habitat conditions (e.g., variations in understorey) or factors acting over coarser scales (e.g., climate, landform) may be spatially structuring local bird assemblages independent of the immediate landscape heterogeneity variables measured (see Barbaro et al. 2007; Haslem and Bennett 2008; Mattsson et al. 2013; Ikin et al. 2014; Kroll et al. 2014). The evidence of spatial autocorrelation, which was largely unrelated to the landscape heterogeneity variables considered in this study, is also highly indicative that not all species respond at a $2 \times 2 \mathrm{~km}$ scale. Many woodland species have a median natal dispersal distance greater than $2 \mathrm{~km}$ (see Garrard et al. 2012 for values) and we 
advocate that further work comparing the response of woodland bird communities at nested spatial scales (e.g., $1 \mathrm{~km}-10 \mathrm{~km}$ ) may prove informative.

Despite the relatively large proportion of unexplained variation, woodland birds did respond significantly to different cues in the landscape and no one variable was overwhelmingly important for the majority of the species considered. This poses some key challenges in terms of biodiversity conservation in wooded-agricultural environments. Firstly, there is no one solution that will benefit the woodland bird community as a whole; even members of the same family possessed varying life-history traits and responded to different landcover variables (see also Graham and Blake 2001; Lee et al. 2002; Bennett et al. 2006). Secondly, at this scale, the observed preferences (or avoidances) of species were most strongly correlated with proximate human-modified landcover types, notably urban areas and coniferous plantations. We cannot conclude that these landcover types are advantageous for woodland bird assemblages; rather it appears that their presence alters the overall community composition. Human demand for resources is expected to grow (Lawton et al. 2010), and ultimately an increasingly urbanised and modified landscape may continue to favour more generalist, ubiquitous species over habitat specialists (Barbaro and van Halder 2009; Katayama et al. 2014).

\section{Acknowledgments}

We are grateful to the Game and Wildlife Conservation Trust for the funding provided and to all the landowners who granted us permission to access their land for survey. 


\section{References}

Atauri JA, de Lucio, JV (2001) The role of landscape structure in species richness distribution of birds, amphibians, reptiles and lepidopterans in Mediterranean landscapes. Landsc Ecol 16:147-159

Aviron S, Burel F, Baudry J, Schermann N (2005) Carabid assemblages in agricultural landscapes: impacts of habitat features, landscape context at different spatial scales and farming intensity. Agric Ecosyst Environ 108:205-217

Barbaro L, van Halder I (2009) Linking bird, carabid beetle and butterfly life history traits to habitat fragmentation in mosaic landscapes. Ecography 32:321-333

Barbaro L, Rossi J-P, Vetillard F, Nezan J, Jactel H (2007) The spatial distribution of birds and carabid beetles in pine plantation forests: the role of landscape composition and structure. J Biogeogr 34:652-664

Bellamy P, Hinsley SA, Newton I (1996) Factors influencing bird species numbers in small woods in south-east England. J Appl Ecol 33:249-262

Bennett AF, Radford JQ, Haslem A (2006) Properties of land mosaics: implications for nature conservation in agricultural environments. Biol Conserv 133:250-264

Bibby CJ, Burgess ND, Hill DA (1992) Bird census techniques. Academic Press, London, UK

Bibby CJ, Burgess ND, Hill DA, Mustoe S, Lambton S (2000) Bird census techniques. $2^{\text {nd }}$ edn. Academic Press, Oxford, UK

Billeter R, Liira J, Bailey D, Bugter R, Arens P, Augenstein I, Aviron S, Baudry J, Bukacek R, Burel F, Cerny M, de Blust G, de Cock R, Diekötter T, Dietz H, Dirksen J, Dormann C, 
Durka W, Frenzel M, Hamersky R, Hendrickx F, Herzog F, Klotz S, Koolstra B, Lausch A, le Couer D, Maelfait JP, Opdam P, Roubalova M, Schermann A, Schermann N, Schmidt T, Schweiger O, Smulders MJM, Speelmans M, Simova P, Verboom J, van Wingerden WKRE, Zobel M, Edwards, PJ (2008) Indicators for biodiversity in agricultural landscapes: A panEuropean study. J Appl Ecol 45:141-150

Bonthoux S, Barnagaud J-Y, Goulard M, Balent, G (2012) Contrasting spatial and temporal responses of bird communities to landscape changes. Oecologia Doi:10.1007/s00442-012$2498-2$

Borcard D, Legendre P (2002) All-scale spatial analysis of ecological data by means of principal coordinates of neighbour matrices. Ecol Model 153:51-68

Broughton RK, Hill RA, Bellamy PE, Hinsley SA (2010) Dispersal, ranging and settling behaviour of marsh tits Poecile palustris in a fragmented landscape in lowland England. Bird Study 57:458-472.

BTO (2014) Welcome to bird facts. [www] Available at: http://www.bto.org/aboutbirds/birdfacts (last accessed 25/02/15)

Cleveland WS (1993) Visualizing data. Hobart Press, New Jersey

Creegan HP, Osborne PE (2005) Gap crossing decisions of woodland songbirds in Scotland: an experimental approach. J Appl Ecol 42:678-687

Daily GC, Ehrlich P, Sánchez-Azofeifa A (2001) Countryside biogeography: use of humandominated habitats by the avifauna of southern Costa Rica. Ecol Appl 11:1-13

Dawson DG, Bull PC (1975) Counting birds in New Zealand forests. Notornis 22:101-10 
Devictor V, Jiguet F (2007) Community richness and stability in agricultural landscapes: the importance of surrounding habitats. Agric Ecosyst Environ 120:179-184

Dray S, Choler P, Dole S, Peres-Neto PR, Thuiller W, Pavoine S, ter Braak CJF (2014)

Combining the fourth-corner and the RLQ methods for assessing trait responses to environmental variation. Ecology 95:14-21

Dunning JB, Danielson BJ, Pulliam HR (1992) Ecological processes that affect populations in complex landscapes. Oikos 65:169-175

ESRI (2011) ArcGIS Desktop: Release 10. Redlands, CA: Environmental Systems Research Institute

Fahrig L, Baudry J, Brotons L, Burel FG, Crist TO, Fuller RJ, Sirami C, Siriwardena G, Martin J-L (2011) Functional landscape heterogeneity and animal biodiversity in agricultural landscapes. Ecol Lett 14:101-112

Fahrig L, Rytwinski T (2009) Effects of roads on animal abundance: an empirical review and synthesis. Ecol Soc 14:21 (online)

Ferguson-Lees J, Castell R, Leech D (2011) A field guide to monitoring nests. British Trust for Ornithology, Thetford, Norfolk

Firbank LG, Petit S, Smart S, Blain A, Fuller RJ (2007) Assessing the impacts of agricultural intensification on biodiversity; a British perspective. Philos Trans R Soc Lond B Biol Sci $363: 777-787$

Forestry Commission (2011) Data from: National Forest Inventory Great Britain 2011. Forestry Commission. Data obtained under Ordnance Survey Open Data terms. Available at: http://www.forestry.gov.uk/forestry/infd-8g5bx3 
Fuller RJ, Trevelyan RJ, Hudson RW (1997) Landscape composition models for breeding bird populations in lowland English farmland over a 20 year period. Ecography 20:295-307

Fuller RJ, Smith KW, Grice PV, Currie FA, Quine CP (2007) Habitat change and woodland birds in Britain: implications for management and future research. Ibis 149:261-268

Garrard GE, McCarthy MA, Vesk PA, Radford JQ, Bennett AF (2012) A predictive model of avian natal dispersal distance provides prior information for investigating response to landscape change. J Anim Ecol 81:14-23

Graham CH, Blake JG (2001) Influence of patch and landscape-level factors on bird assemblages in a fragmented tropical landscape. Ecol Appl 11:1709-1721

Haila Y, Nicholls AO, Hanski IK, Raivio S (1996) Stochasticity in bird habitat selection: year-to-year changes in territory locations in a boreal forest bird assemblage. Oikos 76:536552

Haila Y (2002) A conceptual genealogy of fragmentation research: from island biogeography to landscape ecology. Ecol Appl 12:321-334

Haslem A, Bennett AF (2008) Birds in agricultural mosaics: the influence of landscape pattern and countryside heterogeneity. Ecol Appl 18:185-196

Hausner VH, Yoccoz NG, Ims RA (2003) Selecting indicator traits for monitoring land use impacts: birds in northern coastal birch forests. Ecol Appl 13:999-1012.

Heikkinen RK, Luoto M, Virkkala R, Rainio K (2004) Effects of habitat cover, landscape structure and spatial variables on the abundance of birds in an agricultural forest mosaic. $\mathbf{J}$ Appl Ecol 41:824-835 
Hendrickx F, Maelfait J, Van Wingerden W, Schweiger O, Speelmans M, Aviron S, Augenstein I, Billeter R, Bailey D, Bukacek R, Burel F, Diekotter T, Dirksen J, Herzog F, Liira J, Roubalova M, Vandomme V, Bugter R (2007) How landscape structure, land-use intensity and habitat diversity affect components of total arthropod diversity in agricultural landscapes. J Appl Ecol 44:340-351

Hinsley SA, Bellamy PE, Newton I, Sparks, TH (1995) Habitat and landscape factors influencing the presence of individual breeding bird species in woodland fragments. J Avian Biol 26:94-104

Hinsley SA, Bellamy PE (2000) The influence of hedge structure, management and landscape context on the value of hedgerows to birds: a review. J Environ Manag 80:33-49

Ikin K, Barton PS, Stirnemann IA, Stein JR, Michael D, Crane M, Okada S, Lindenmayer DB (2014) Multi-scale associations between vegetation cover and woodland bird communities across a large agricultural region. PLoS ONE 9:1-12

Jiguet F, Devictor V, Julliard R, Couvet D (2011) French citizens monitoring ordinary birds provide tools for conservation and ecological sciences. Acta Oecol 1:doi:10.1016/j.actao.2011.05.003

Katayama N, Amano T, Naoe S, Yamakita T, Komatsu I (2014) Landscape heterogeneitybiodiversity relationship: effect of range size. PLoS ONE 9(3):1-8

Kennedy CM, Marra PP, Fagan WF, Nell MC (2010) Landscape matrix and species traits mediate responses of Neotropical resident birds to forest fragmentation in Jamaica. Ecol Monogr 80(4):651-669 
Kroll AJ, Ren Y, Jones JE, Giovanini J, Perry RW, Thill RE, White D, Wigley TB (2014) Avian community composition associated with interactions between local and landscape habitat attributes. For Ecol Manag 326:46-57

Kupfer JA, Malanson GP, Franklin SB (2006) Not seeing the ocean for the islands: the mediating influence of matrix-based processes on forest fragmentation effects. Global Ecol Biogeogr 15:8-20

Lawton JH, Brotherton PNM, Brown VK, Elphick C, Fitter AH, Forshaw J, Haddow RW, Hilborne S, Leafe RN, Mace GM, Southgate MP, Sutherland WJ, Tew TE, Varley J, Wynne GR (2010) Making Space for Nature: a review of England's wildlife sites and ecological network. Report to Defra

Lee M, Fahrig L, Freemark K, Currie DJ (2002) Importance of patch scale vs. landscape scale on selected forest birds. Oikos 96:110-118

Legendre P, Legendre L (1998) Numerical Ecology. $2^{\text {nd }}$ edn. Elsevier Science, Amsterdam, Netherlands

Lindenmayer DB, Cunningham RB, Donnelly CF, Nix H, Lindenmayer BD (2002) Effects of forest fragmentation on bird assemblages in a novel landscape context. Ecol Monogr 72:1-18 Mason WL (2007) Changes in the management of British forests between 1945 and 2000 and possible future trends. Ibis 149:41-52

Mattsson BJ, Zipkin EF, Gardner B, Blank PJ, Sauer RJ, Royle A (2013) Explaining localscale species distributions: relative contributions of spatial autocorrelation and landscape heterogeneity for an avian assemblage. PLoS ONE 8(2):e55097 
Mayfield M, Bonser SP, Morgan J, Aubin I, McNamara S, Vesk PA (2010) What does species richness tell us about functional trait diversity? Predictions and evidence for responses of species and functional trait diversity to land-use change. Global Ecol Biogeogr $19: 423-431$

McGarigal K, Ene E (2012) Fragstats 4.1: A Spatial Pattern Analysis Program for Categorical Maps. Computer software program produced by the authors at the University of Massachusetts, Amherst. Available at: http://www.umass.edu/landeco/research/fragstats/fragstats.html Mimet A, Maurel N, Pellissier V, Simon L, Julliard R (2014) Towards a unique landscape description for multi-species studies: A model comparison with common birds in a humandominated French region. Ecol Indic 36:19-32

Mortelliti A, Fagiani S, Battisti C, Capizzi D, Boitani L (2010) Independent effects of habitat loss, habitat fragmentation and structural connectivity on forest-dependent birds. Divers Distrib 16:941-951

Morton D, Rowland C, Wood C, Meek L (2011) Final Report for LCM2007 - the new UK Land Cover Map. Countryside Survey Technical Report No 11/07. Natural Environment Research Council (NERC). Centre for Ecology and Hydrology (CEH), Oxfordshire Natural England (2013) Download Environmental Data: Ancient Woodlands. Coverage: Great Britain. Obtained under non-commerical licence. Available at: http://www.geostore.com/environment-agency/WebStore?xml=environmentagency/xml/ogcDataDownload.xml

Neuschulz EL, Brown M, Farwig N (2012) Frequent bird movements across a highly fragmented landscape: the role of species traits and forest matrix. Anim Conserv 16:170-179 
Neumann JL, Griffiths GH, Hoodless A, Holloway GJ (2015) The compositional and configurational heterogeneity of matrix habitats shape woodland carabid communities in wooded-agricultural landscapes. Landsc Ecol Doi:10.1007/s10980-015-0244-y

Oliver T, Roy DB, Hill JK, Brereton T, Thomas CD (2010) Heterogeneous landscapes promote population stability. Ecol Lett 13:473-484

Ordnance Survey (2010) Data from: MasterMap Download. Edina Digimap. Data obtained under licence. Available at: http://digimap.edina.ac.uk/mastermapdownloader/Downloader Ordnance Survey (2012) Data from: OS Open Source. Coverage: Great Britain. Updated 2011, Ordnance Survey Open Data, GB. Available at: http://www.ordnancesurvey.co.uk/oswebsite/products/

Osborne P (1984) Bird numbers and habitat characteristics in farmland hedgerows. J Appl Ecol 21:63-82

Pino J, Roda F, Ribas J, Pons X (2000) Landscape structure and bird species richness: implications for conservation in rural areas between natural parks. Landsc Urban Plann $49: 35-48$

Polak M, Wiacek J, Kucharczyk M, Orzechowski R (2013) The effect of road traffic on a breeding community of forest birds. Eur J Forest Res 132:931-941

Rackham O (2003) Ancient woodland: its history, vegetation and uses in England. $2^{\text {nd }}$ edn. Castlepoint Press, UK

Radford JQ, Bennett AF (2007) The relative importance of landscape properties for woodland birds in agricultural environments. J Appl Ecol 44(4):737-747 
Reijnen R, Foppen R, Ter Braak C, Thiessen J (1995) The effects of car traffic on breeding bird populations in woodland. III. Reduction of density in relation to the proximity of main roads. J Appl Ecol 32:187-202

Reijnen R, Foppen R (2006) Impact of road traffic on breeding bird populations. In:

Davenport J, Davenport JL (eds). The ecology of transportation: managing mobility for the environment. pp.255-274. Springer, Netherlands

Rodewald AD (2003) The importance of land uses within the landscape matrix. Wildl Soc Bull 31:586-592

Schweiger O, Maelfait JP, Van Wingerden W, Hendrickx F, Billeter R, Speelmans M, Augenstein I, Aukema B, Aviron S, Bailey D, Bukacek R, Burel F, Diekötter T, Dirksen J, Frenzel M, Herzog F, Liira J, Roubolava M, Bugter R (2005) Quantifying the impact of environmental factors on arthropod communities in agricultural landscapes across organizational levels and spatial scales. J Appl Ecol 42:1129-1139

Siffczyk C, Brotons L, Kangas K, Orell M (2003) Home range size of willow tits: a response to winter habitat loss. Oecologia 136:635-642

Šmilauer P, Leps J (2014) Multivariate analysis of ecological data using Canoco 5. $2^{\text {nd }}$ edn. Cambridge University Press, UK

Snow DW, Perrins CM (1998) The birds of the western Palearctic. Concise edn. Oxford University Press

Sorace A, Gustin M, Calvario E, Ianniello L, Sarrocco S, Carere C (2000) Assessing bird communities by point counts: repeated sessions and their duration. Acta Ornithol 35:197-202 
Sutherland WJ (2006) Ecological census techniques: a handbook. $2^{\text {nd }}$ edn. Cambridge University Press, Cambridge, UK

Taylor PD, Fahrig L, Henein K, Merriam G (1993) Connectivity is a vital element of landscape structure. Oikos 68:571-573

Ter Braak CJF, Šmilauer P (2012) Canoco reference manual and user's guide: software for ordination. Version 5.0. Microcomputer Power, Ithaca, USA

Terra Metrics (2009) Google Maps UK. Available at: https://www.google.co.uk/maps/ (last accessed 17/10/2011)

Tscharntke T, Klein AM, Kruess A, Steffan-Dewenter I, Thies C (2005) Landscape perspectives on agricultural intensification and biodiversity - ecosystem service management. Ecol Lett 8:857-874

Virkkala R, Luoto M, Rainio K (2004) Effects of landscape composition on farmland and red-listed birds in boreal agricultural-forest mosaics. Ecography 27:273-284 
Appendix 1: Record of woodland bird life-history and ecological traits.

\begin{tabular}{|c|c|c|c|c|c|c|}
\hline Species & Family & Weight (g) & Nest location & Breeding food & Foraging strata & Woodland association \\
\hline Blackbird & Thrushes & 100 & Tree or Hedge & Invertebrates \& Fruit & Ground or Herb Layer & Mixed \\
\hline Blackcap & Scrub warblers & 21 & Ground or Herb Layer & Invertebrates & Shrub Layer & Shrub \\
\hline Blue tit & Tits & 11 & Hole & Invertebrates & Diverse & Ubiquitous \\
\hline Bullfinch & Finches & 21 & Shrub & Invertebrates \& Seeds & Branches & Mixed \\
\hline Chaffinch & Finches & 24 & Tree or Hedge & Invertebrates \& Seeds & Diverse & Mixed \\
\hline Chiffchaff & Leaf warblers & 9 & Ground or Herb Layer & Invertebrates & Foliage Gleaner & Mixed \\
\hline Coal tit & Tits & 9 & Ground or Herb Layer & Invertebrates & Diverse & Coniferous \\
\hline Cuckoo & Cuckoos & 120 & Variable & Invertebrates & Diverse & Open \\
\hline Dunnock & Accentors & 21 & Shrub & Invertebrates & Ground or Herb Layer & Shrub \\
\hline Firecrest & Kinglets & 6 & Tree or Hedge & Invertebrates & Foliage Gleaner & Coniferous \\
\hline $\begin{array}{l}\text { Great spotted } \\
\text { Woodpecker }\end{array}$ & Woodpeckers & 85 & Hole & Invertebrates \& Seeds & Trunks & Mixed \\
\hline
\end{tabular}




\begin{tabular}{|c|c|c|c|c|c|c|}
\hline Garden warbler & Scrub warblers & 19 & Ground or Herb Layer & Invertebrates & Shrub Layer & Edge \\
\hline Goldcrest & Kinglets & 6 & Tree or Hedge & Invertebrates & Foliage Gleaner & Coniferous \\
\hline Goldfinch & Finches & 17 & Tree or Hedge & Invertebrates \& Seeds & Diverse & Open \\
\hline Great tit & Tits & 18 & Hole & Invertebrates & Diverse & Ubiquitous \\
\hline $\begin{array}{l}\text { Green } \\
\text { Woodpecker }\end{array}$ & Woodpeckers & 190 & Hole & Invertebrates & Ground or Herb Layer & Open \\
\hline Greenfinch & Finches & 28 & Tree or Hedge & Invertebrates \& Seeds & Diverse & Open \\
\hline Lesser redpoll & Finches & 11 & Tree or Hedge & Invertebrates \& Seeds & Branches & Mixed \\
\hline Long-tailed tit & Tits & 9 & Shrub & Invertebrates & Diverse & Edge \\
\hline Marsh tit & Tits & 12 & Hole & Invertebrates & Diverse & Broadleaved \\
\hline Mistle thrush & Thrushes & 130 & Tree or Hedge & Invertebrates & Ground or Herb Layer & Mixed \\
\hline Nuthatch & Nuthatches & 24 & Hole & Invertebrates & Trunks & Mixed \\
\hline Robin & Chats & 18 & Variable & Invertebrates & Ground or Herb Layer & Shrub \\
\hline
\end{tabular}




\begin{tabular}{|c|c|c|c|c|c|c|}
\hline Siskin & Finches & 15 & Tree or Hedge & Invertebrates \& Seeds & Branches & Coniferous \\
\hline Song thrush & Thrushes & 83 & Tree or Hedge & Invertebrates \& Fruit & Ground or Herb Layer & Mixed \\
\hline Stock dove & Pigeons & 300 & Hole & Invertebrates \& Seeds & Diverse & Mixed \\
\hline Tree pipit & $\begin{array}{l}\text { Wagtails \& } \\
\text { pipits }\end{array}$ & 24 & Ground or Herb Layer & Invertebrates & Ground or Herb Layer & Open \\
\hline Treecreeper & Treecreepers & 10 & Hole & Invertebrates & Trunks & Mixed \\
\hline Willow tit & Tits & 12 & Hole & Invertebrates & Diverse & Broadleaved \\
\hline Willow warbler & Leaf warblers & 10 & Ground or Herb Layer & Invertebrates & Foliage Gleaner & Mixed \\
\hline Woodlark & Larks & 30 & Ground or Herb Layer & Invertebrates \& Seeds & Ground or Herb Layer & Edge \\
\hline Wren & Wrens & 10 & Variable & Invertebrates & Ground or Herb Layer & Shrub \\
\hline
\end{tabular}

